\title{
Effect of parity and stage of lactation on feed sorting behavior of lactating dairy cows
}

\author{
T. J. DeVries, ${ }^{* 1}$ L. Holtshausen, $†$ M. Oba, $\ddagger$ and K. A. Beauchemin† \\ *Department of Animal and Poultry Science, University of Guelph, Kemptville Campus, 830 Prescott Street, Kemptville, ON, Canada, K0G 1J0 \\ †Agriculture and Agri-Food Canada, Lethbridge, AB, Canada, T1J 4B1 \\ ‡Department of Agriculture, Food and Nutritional Science, University of Alberta, Edmonton, AB, Canada, T6G 2P5
}

\section{ABSTRACT}

The objectives of this study were to determine if feed sorting differs between primiparous (PP) and multiparous (MP) cows, if sorting changes from the period of peak lactation to peak dry matter intake (DMI), and whether feed sorting affects efficiency of production. Data on DMI, milk production, feed sorting (particle size of offered and refused feed), and energy status (plasma nonesterified fatty acid, $\beta$-hydroxybutyrate, insulin and glucose concentration) were collected on 30 PP and 30 MP lactating Holstein dairy cows, individually housed and fed in tie-stalls, during 3 wk (wk 2, 6, and 10) over 10 wk of a lactation study. Cows averaged 53,81 , and $109 \pm 10 \mathrm{~d}$ in milk (DIM) at the beginning of each of the 3 recording weeks. To determine sorting, feed samples were separated with a particle separator that had 3 screens $(19,8$, and $1.18 \mathrm{~mm})$ and a bottom pan, resulting in 4 fractions (long, medium, short, fine). Over the study period, MP cows consumed more DM and produced more milk than did the PP cows, but had similar efficiency of production ( $\mathrm{kg}$ of milk/ $\mathrm{kg}$ of DMI), and similar levels of plasma indicators of energy status. Across the study period, DMI increased, whereas milk yield decreased, resulting in decreased efficiency of milk production as cows moved further into lactation. All cows had higher nonesterified fatty acid and lower insulin concentrations in plasma at 53 DIM compared with at 81 and 109 DIM, suggesting they were mobilizing more body fat at that earlier stage of lactation. Across periods, all cows sorted against the longest ration particles, did not sort the medium ration particles, and sorted for fine ration particles; as a result, all cows consumed less neutral detergent fiber (NDF) and physically effective NDF (proportion of NDF retained on the 19- and 8-mm screens of the particle separator) than predicted. Greater selection against the longest ration particles was associated with greater efficiency

Received February 11, 2011.

Accepted April 26, 2011

${ }^{1}$ Corresponding author: tdevries@uoguelph.ca of milk production; however, this sorting pattern also tended to be associated with lower milk fat percentage. The extent of the observed sorting against the longest, physically effective ration particles and for the finest ration particles was greater for PP cows than for MP cows across all 3 observation periods. Feed sorting remained consistent in cows across the DIM evaluated in this study and that this sorting behavior can affect the efficiency of milk production as well as milk fat percentage. Further, PP cows engage in more sorting of their ration than MP cows.

Key words: sorting, dairy cow, parity, stage of lactation

\section{INTRODUCTION}

Inefficiencies in feed use can arise from excessive selective consumption (sorting) of a TMR. Excessive sorting of a TMR can result in overconsumption (relative to anticipated intake based on dietary formulation) of rapidly fermentable carbohydrates and increase the risk of subacute ruminal acidosis (SARA; DeVries et al., 2008). Alternatively, sorting of the TMR can decrease the nutritive value of the TMR remaining in the feed bunk, particularly in the later hours after feed delivery (DeVries et al., 2005). This may be detrimental for those cows that, in a group-feeding situation, do not have good access to feed at the time when it is delivered. Sorting of a TMR, therefore, may lead to inconsistencies and imbalances in nutrient intake both within, and between dairy cows, and may lead to inefficiencies in feed use in both individually housed and group-housed dairy cows.

The susceptibility of dairy cows to SARA appears to be highest for cows in early lactation (Penner et al., 2007), particularly primiparous (PP) cows (Krause and Oetzel, 2006). One possible contributor to this may be differences in feeding patterns between PP and multiparous (MP) cows (Krause and Oetzel, 2006). This susceptibility is also highly variable among cows, despite similar cow feeding management (Penner et al., 2007). This variability may be due to variable nutrient intake within a day arising from sorting rations against 
physically-effective fiber (DeVries et al., 2008). Interestingly, one of the clinical manifestations of SARA is inconsistent feed intake, which is associated with other effects, including decreased efficiency of milk production (Nocek, 1997). We, therefore, hypothesized that variability in nutrient intake, as a result of feed sorting, may contribute to decreased production efficiency. Alternatively, ruminants have been shown to select feeds in an attempt to compensate for imbalances in the nutrient content of their diet (e.g., protein in dairy cows, Tolkamp et al., 1998; protein and energy in sheep, Villalba and Provenza, 1999; physically effective fiber in dairy cows, Yang and Beauchemin, 2006c). We, therefore, hypothesized that feed sorting by dairy cows may vary with changing nutritional requirements over different stages of lactation. Thus, the objectives of this study were to determine if feed sorting differs between $\mathrm{PP}$ and MP cows, determine if sorting changes from peak lactation to peak DMI, and determine the effect feed sorting has on efficiency of milk production.

\section{MATERIALS AND METHODS}

This study was part of a larger study aimed at evaluating the potential of a fibrolytic enzyme additive to improve fiber digestion and milk production in dairy cows. As such, extensive details of the methodology of the study are found in Holtshausen et al. (2011). The study was conducted at the University of Alberta Dairy Research and Technology Center (DRTC, Edmonton, AB, Canada). Sixty lactating Holstein dairy cows (30 PP and $30 \mathrm{MP} ; 46 \pm 10 \mathrm{DIM}$ at the start of the experimental period) were blocked by parity and then randomly assigned to one of 3 treatments: (1) control diet (no enzyme), (2) low enzyme [control treated with $0.5 \mathrm{~mL}$ of Econase RDE (AB Vista, Marlborough, UK) $/ \mathrm{kg}$ of TMR DM], and (3) high enzyme (control treated with $1.0 \mathrm{~mL}$ of Econase RDE/ $\mathrm{kg}$ of TMR DM). Each treatment group, thus, contained 10 PP and $10 \mathrm{MP}$ cows. Groups of cows were sequentially enrolled in the study every 2 wk over a 6 -mo period. All cows were fed the DRTC standard early-lactation diet for a 2 -wk adjustment period followed by a 10 -wk experimental period on their assigned diet. The entire study period lasted from January to September 2009. The cows were fed with ad libitum intake once daily at $0800 \mathrm{~h}$. The control diet (Table 1) was formulated using the Cornell-Penn-Miner System (CPM-Dairy, Version 3.0.4a; Cornell University, Ithaca, NY; University of Pennsylvania, Kennett Square, PA; and William H. Miner Agricultural Research Institute, Chazy, NY) to provide adequate ME and MP for a $605-\mathrm{kg}$ cow producing $39 \mathrm{~kg}$ of milk/d containing $3.5 \%$ fat and $3.3 \%$ protein, and assuming a DMI of $23 \mathrm{~kg} / \mathrm{d}$. Further details on preparation of the diets and addition of the enzyme, and water in the case of the control diet, are described in Holtshausen et al. (2011). Cows were housed individually in a ventilated tie-stall barn, had free access to water, and were exercised daily $(2 \mathrm{~h})$ in an open dry lot. Cows were milked in their stalls twice daily at 0400 and $1400 \mathrm{~h}$. All cows were cared for in accordance with the guidelines of the Canadian Council on Animal Care (1993).

During the 10-wk experimental period data were collected on the cows during 3 recording weeks (wks 2, 6, and 10). Cows averaged 53, 81, and $109 \pm 10$ DIM at the beginning of each of the 3 recording weeks (53D, 81D, and 109D, respectively). Feed offered and refused were recorded daily during those 7 -d periods. Samples of the control TMR and diet ingredients (forages and concentrate) were collected on $1 \mathrm{~d}$ during the recording weeks; orts samples for individual cows were collected and composited for 3 consecutive days during

Table 1. Ingredients and chemical composition (mean \pm SD) of the control diet

\begin{tabular}{lc}
\hline & $\begin{array}{c}\text { \% of Diet, } \\
\text { DM }\end{array}$ \\
Composition & \\
\hline Ingredient $^{1}$ & 20.6 \\
Barley silage $^{2}$ & 20.6 \\
Alfalfa silage $^{3}$ & 10.8 \\
Alfalfa hay $^{4}$ & 9.52 \\
Barley grain, steam rolled $_{\text {Corn grain, steam rolled }}$ & 8.88 \\
By-pass soybean meal $^{5}$ & 6.60 \\
Corn, dry ground & 6.00 \\
Barley, dry ground & 5.16 \\
Soybean meal & 4.32 \\
Corn distillers grains with solubles & 3.36 \\
Canola meal & 2.52 \\
Limestone & 0.41 \\
Sodium bicarbonate & 0.39 \\
Salt & 0.33 \\
Magnesium oxide & 0.19 \\
Dicalcium phosphate & 0.17 \\
Trace mineral premix & \\
Chemical composition & 0.15 \\
DM & \\
OM, \% of DM & $52.9 \pm 3.62$ \\
CP, \% of DM & $89.5 \pm 0.56$ \\
NDF, \% of DM & $20.0 \pm 1.00$ \\
ADF, \% of DM & $33.9 \pm 1.82$ \\
Starch, \% of DM & $23.9 \pm 1.49$ \\
1Al ing & $16.5 \pm 1.79$ \\
\hline
\end{tabular}

${ }^{1}$ All ingredients except alfalfa hay, alfalfa silage, and barley silage were provided as part of a ground concentrate mix.

${ }^{2}$ Composition (DM basis): $35.3 \% \mathrm{DM}, 15.0 \% \mathrm{CP}, 53.2 \% \mathrm{NDF}$, and $34.2 \% \mathrm{ADF}$.

${ }^{3}$ Composition (DM basis): $39.8 \% \mathrm{DM}, 18.9 \% \mathrm{CP}, 37.2 \% \mathrm{NDF}$, and $32.2 \%$ ADF.

${ }^{4}$ Composition (DM basis): $89.5 \% \mathrm{DM}, 16.8 \% \mathrm{CP}, 47.4 \% \mathrm{NDF}$, and $36.6 \% \mathrm{ADF}$

${ }^{5}$ Aminoplus (Ag Processing Inc., Omaha, NE).

${ }^{6}$ Added to supply per kilogram of dietary DM: $65 \mathrm{mg}$ of Mn, $110 \mathrm{mg}$ of $\mathrm{Zn}, 37 \mathrm{mg}$ of $\mathrm{Cu}, 1 \mathrm{mg}$ of Co, $0.30 \mathrm{mg}$ of Se, 8,336 IU of vitamin A, $834 \mathrm{IU}$ of vitamin $\mathrm{D}$, and $56 \mathrm{IU}$ of vitamin $\mathrm{E}$. 
the recording weeks. All samples for DM and nutrient analysis were dried for $48 \mathrm{~h}$ at $60^{\circ} \mathrm{C}$, and ground through a 1-mm screen (standard model 4; Arthur H. Thomas Co., Philadelphia, PA). Samples for particle size separation were frozen at $-20^{\circ} \mathrm{C}$ until they were further analyzed. Samples for particle size separation (Table 2) were thawed and separated using a 3 -screen (19, 8, and $1.18 \mathrm{~mm}$ ) Penn State Particle Separator (PSPS; Kononoff et al., 2003). This separated the samples into 4 fractions: long $(>19 \mathrm{~mm})$, medium $(<19,>8 \mathrm{~mm})$, short $(<8,>1.18 \mathrm{~mm})$, and fine $(<1.18 \mathrm{~mm})$ particles. After separation, the DM of each separated fraction was determined by forced-air drying at $60^{\circ} \mathrm{C}$ for $48 \mathrm{~h}$. Feed samples were analyzed for analytical DM, OM, $\mathrm{NDF}, \mathrm{ADF}$, and $\mathrm{CP}$ content using the methodologies described by Holtshausen et al. (2011). In addition to those methods listed, starch content was also determined enzymatically after gelatinization as described by Rode et al. (1999).

Milk weight was recorded daily (a.m. and p.m.) during the 3 recording weeks of the experimental period from each cow to determine milk production. Milk samples were taken on 3 consecutive days during every recording week. Samples were preserved with potassium dichromate, stored at $4^{\circ} \mathrm{C}$, and sent to the Central Alberta Milk Testing Laboratory (Edmonton, $\mathrm{AB}$, Canada) for milk fat, CP, and lactose analyses using an infrared analyzer (MilkoScan 605; Foss Electric, Hillerød, Denmark; AOAC, 2002; method 972.16). Milk component percentage and weight were adjusted for a.m. and p.m. milk weights. The yield of $3.5 \%$ FCM $(\mathrm{kg} / \mathrm{d})$ was calculated as $0.432 \times$ milk yield $(\mathrm{kg} / \mathrm{d})+$ $16.23 \times$ fat yield $(\mathrm{kg} / \mathrm{d})$. The efficiency of milk production was determined by calculating the kilograms of milk or $3.5 \%$ FCM yield per kilogram of DMI.

Blood samples were taken from the coccygeal vessel every $18 \mathrm{~h}$ over a 3 -d period $(1300,0700,0100$, and $1900 \mathrm{~h}$, representing every $6 \mathrm{~h}$ of a 24 -h period, accounting for diurnal variation) during wk 2,6 , and 10 of the experimental period. Blood was sampled into Vacutainer tubes (Becton Dickinson, Franklin Lakes, NJ) containing sodium heparin, immediately placed on ice and centrifuged at $3,000 \times g$ for $30 \mathrm{~min}$ at $4^{\circ} \mathrm{C}$ within $1 \mathrm{~h}$ after collection. Plasma was harvested and stored at $-20^{\circ} \mathrm{C}$ until the end of the sampling week at which point plasma samples were pooled by cow and again stored at $-20^{\circ} \mathrm{C}$ until analyzed. Plasma concentrations of NEFA, BHBA, insulin, and glucose were later determined using the methodologies described by Holtshausen et al. (2011).

Ration physical effectiveness factor was determined as the DM proportion of particles retained by the top 2 sieves of the PSPS (Yang and Beauchemin, 2006a). The physically effective NDF (peNDF) was calcu-
Table 2. Particle size ${ }^{1}$ distribution of the TMR and CP, NDF, ADF, and starch content of the particle fractions fed to lactating dairy cows (means $\pm \mathrm{SD})$

\begin{tabular}{lc}
\hline Particle size & Distribution \\
\hline \% DM retained on screen & \\
Long & $18.4 \pm 6.5$ \\
Medium & $33.6 \pm 5.5$ \\
Short & $33.4 \pm 2.6$ \\
Fine & $14.6 \pm 2.3$ \\
CP, \% of screen DM & \\
Long & $14.2 \pm 0.7$ \\
Medium & $14.2 \pm 0.9$ \\
Short & $20.6 \pm 2.1$ \\
Fine & $24.9 \pm 1.2$ \\
NDF, \% of screen DM & \\
Long & $50.4 \pm 1.9$ \\
Medium & $40.2 \pm 2.4$ \\
Short & $25.8 \pm 2.3$ \\
Fine & $23.8 \pm 1.3$ \\
ADF, \% of screen DM & \\
Long & $36.0 \pm 1.8$ \\
Medium & $26.1 \pm 2.0$ \\
Short & $14.2 \pm 1.4$ \\
Fine & $12.3 \pm 1.0$ \\
Starch, \% of screen DM & \\
Long & $4.0 \pm 1.2$ \\
Medium & Short \\
Fine & pef
\end{tabular}

${ }^{1}$ Particle size determined by Penn State Particle Separator which has a 19-mm screen (long), 8-mm screen (medium), 1.18-mm screen (short), and a pan (fine).

${ }^{2}$ Physical effectiveness factor, determined as the proportion of particles retained by the top 2 sieves of the Penn State Particle Separator (Yang and Beauchemin, 2006a).

${ }^{3}$ Physically effective NDF, measured as the NDF content of the TMR (DM basis) multiplied by the pef.

lated by multiplying the NDF content of the feed by the physical effectiveness factor. Sorting activity (for each fraction of the PSPS and for CP, ADF, NDF, and peNDF) was calculated as the actual DMI of each variable expressed as a percentage of the predicted DMI of that variable (Leonardi and Armentano, 2003). The actual DMI of each individual variable was calculated as the difference between the DM amount of each variable in the offered TMR and that in the refused feed. The predicted intake for each individual variable was calculated as the product of the DMI of the total diet multiplied by the DM percentage of that variable in the TMR fed. Values equal to $100 \%$ indicate no sorting, $<100 \%$ indicate selective refusals (sorting against), and $>100 \%$ indicate preferential consumption (sorting for).

Data for production data and sorting were summarized for each cow by recording week. Preliminary screening of the data revealed that all dependent variables were normally distributed. To ensure no seasonal effect on the dependent variables, a preliminary analysis was conducted to determine the effect of group (i.e., 
each enrolled at 2-wk intervals over the study period). This analysis revealed no significant effect of group; therefore, group was considered a random effect in the analyses. To test whether sorting of the experimental diets occurred, sorting activity data (for each PSPS fraction, $\mathrm{CP}, \mathrm{ADF}, \mathrm{NDF}$, and peNDF) were summarized by treatment and tested for a difference from 100 using $t$-tests. To test for differences among treatments, weeks and parity, all data were analyzed in a repeated measures mixed model using the MIXED procedure of SAS (SAS Institute, 2003). In the model, parity, week, enzyme treatment, and their interaction terms were considered fixed effects, whereas group and cow within group, treatment, and parity were considered random effects. Week was considered as a repeated measure. The variance-covariance error structure was compound symmetry, heterogeneous compound symmetry, or first-order heterogeneous autoregressive, depending upon the best fit according to Schwarz's Bayesian information criterion. To determine the effect feed sorting had on efficiency of milk production and production parameters, sorting activity data were individually included as a continuous linear effect in the above mentioned model; only those significant effects are further reported. None of the interactions tested in the models were significant; therefore, these are not further reported. All values reported are least squares means. Significance was declared as $P \leq 0.05$ and trends were reported if $0.05<P \leq 0.10$.

\section{RESULTS AND DISCUSSION}

This study on feed sorting was part of a larger study aimed at evaluating the potential of a developmental fibrolytic enzyme additive to improve fiber digestion and milk production in dairy cows (Holtshausen et al., 2011). As described by Holtshausen et al. (2011) across the 10-wk duration of the study, the addition of enzyme did affect the production of the cows during the 3 recording weeks (wks 2, 6, and 10); notably, DMI was decreased $($ control $=25.0 \mathrm{~kg} / \mathrm{d}$, low enzyme $=23.0$ $\mathrm{kg} / \mathrm{d}$, high enzyme $=22.6 \mathrm{~kg} / \mathrm{d} ; \mathrm{SE}=0.7 ; P=0.03)$ and efficiency of FCM production tended $(P=0.08)$ to increase (control $=1.50 \mathrm{~kg}$ of FCM $/ \mathrm{kg}$ of DMI, low enzyme $=1.56 \mathrm{~kg}$ of $\mathrm{FCM} / \mathrm{kg}$ of DMI, high enzyme $=$ $1.66 \mathrm{~kg}$ of $\mathrm{FCM} / \mathrm{kg}$ of DMI; SE $=0.05)$ with the addition of enzyme. Enzyme addition had no significant effect on the sorting (\% of predicted intake) behavior of the cows, with the exception of sorting of medium ration particles. Even though the treatment values differed $($ control $=100.0 \%$, low enzyme $=100.1 \%$, high enzyme $=100.9 \% ; \mathrm{SE}=0.24 ; P=0.003)$, the values for sorting of medium particles across the study were not different from $100 \%$ (Table 3), indicating that across treatments actually no sorting occurred for or against this particle fraction. Given that the primary objective of this part of the study was to compare sorting behavior between parities and across weeks of lactation, the effect of enzyme addition, beyond being accounted for in our statistical models, is not further considered.

Over the study period, MP cows consumed more DM and produced more milk than the PP cows (Table 4). Cows in their first lactation typically consume less DM and produce less milk than do MP cows (Dado and Allen, 1994; Beauchemin et al., 2002; Azizi et al., 2009), given that DMI is positively correlated with milk production (Dado and Allen, 1994). Because both DMI and milk production were proportionally lower for PP cows than for MP cows, it is not surprising that production efficiency was similar for both groups of cows. As energy balance (as reflected in NEFA and insulin levels) of the MP and PP was similar across time periods, it can also be concluded that no difference existed in digestion efficiency between the MP and PP cows.

Across the study period DMI increased, whereas milk yield decreased (Table 4). This was predictable as cows moved from their period of peak lactation to a period of peak DMI (Kertz et al., 1991). As a result of this, the efficiency of milk production decreased in all cows as they went from, on average, 53D to 109D. The increased efficiency of milk production at 53D was likely not attributable to any difference in digestibility at that time, rather it may be attributed to the mobilization of body reserves. All cows had higher plasma NEFA and lower plasma insulin levels at 53D compared with 81D and 109D. Elevated NEFA levels suggest that cows were mobilizing more body reserves (Grummer, 1993) and lower insulin levels suggest cows were utilizing most of their available energy (i.e., blood glucose; Block et al., 2001) at this stage of lactation to meet the demands of production. Interestingly, plasma BHBA levels were no higher at 53D compared with the other recording weeks, suggesting that cows were consuming enough DM to provide sufficient precursors to allow the liver to oxidize the NEFA to a similar extent as in later stages of lactation (Grummer, 1993).

Across the study periods, all cows sorted against the longest ration particles, did not sort the medium ration particles, and sorted for fine ration particles (Table $3)$. This sorting pattern is typical and indicates, as described previously (Leonardi and Armentano, 2003; DeVries et al., 2007), that cows were selecting against the long, fibrous forage particles and for the fine particles, which consisted of highly palatable concentrate components high in starch (DeVries et al., 2008). The degree of sorting observed is similar to that reported in other studies with similar ration characteristics and particle size distribution (Leonardi and Armentano, 
Table 3. Sorting behavior ${ }^{1}$ results for primiparous and multiparous cows $\left(\mathrm{L}^{2}\right)$ during 3 different time points during lactation $\left(\mathrm{W}^{3}\right)$

\begin{tabular}{|c|c|c|c|c|c|c|c|c|c|}
\hline Item & \multicolumn{3}{|c|}{ Primiparous } & \multicolumn{3}{|c|}{ Multiparous } & $\mathrm{SE}$ & \multicolumn{2}{|c|}{$P$-value } \\
\hline \multicolumn{10}{|c|}{ Sorting of particle fractions, ${ }^{4} \%$} \\
\hline Medium & 100.1 & 100.2 & 100.5 & 100.4 & 100.4 & 100.4 & 0.4 & 0.71 & 0.81 \\
\hline Short & $100.8 \dagger$ & $101.1^{*}$ & $101.2^{*}$ & 100.2 & 100.4 & 99.9 & 0.4 & 0.10 & 0.29 \\
\hline Fine & $104.2^{*}$ & $104.3^{*}$ & $103.4^{*}$ & 103.1* & $102.9^{*}$ & $102.8^{*}$ & 0.5 & 0.01 & 0.27 \\
\hline \multicolumn{10}{|c|}{ Sorting of dietary nutrients, $\%$} \\
\hline $\mathrm{NDF}$ & $98.6^{*}$ & $98.7^{*}$ & $98.9^{*}$ & $99.0^{*}$ & $99.0^{*}$ & $98.8^{*}$ & 0.2 & 0.48 & 0.71 \\
\hline peNDF $^{5}$ & $96.4^{*}$ & $96.4^{*}$ & $96.9^{*}$ & $97.7^{*}$ & $97.6^{*}$ & $97.6^{*}$ & 0.6 & 0.10 & 0.71 \\
\hline
\end{tabular}

${ }^{1}$ Sorting $\%=100 \times(\mathrm{n} \mathrm{DMI} / \mathrm{n}$ predicted DMI), where $\mathrm{n}=$ particle fraction (long, medium, short, or fine) or dietary nutrient $(\mathrm{CP}, \mathrm{ADF}, \mathrm{NDF}$, or peNDF). Sorting values equal to $100 \%$ indicate no sorting, $<100 \%$ indicate selective refusals (sorting against), and $>100 \%$ indicate preferential consumption (sorting for).

${ }^{2} 30$ primiparous and 30 multiparous cows.

${ }^{3}$ Recording wk 2, 6, and 10 of a 10-wk experimental period. Cows averaged 53, 81, and $109 \pm 10$ DIM at the beginning of each of the 3 recording weeks.

${ }^{4}$ Particle size determined by the Penn State Particle Separator with 19-mm (long), 8-mm (medium), 1.18-mm (short) screens, and a pan (fine). ${ }^{5}$ Physically effective NDF

${ }^{*} P<0.05 ; \nmid P<0.10$ (for differences in sorting values from $100 \%$ ).

2003; Leonardi et al., 2005; DeVries et al., 2007). It is not surprising that as a result of such sorting all cows consumed less NDF and peNDF than predicted. It should be noted that the actual decrease in peNDF intake due to sorting in this study is likely underestimated, because we did not account for the differences in NDF content of the material on the various particle separator screens (Table 2; i.e., use of fractional NDF content of the screens versus total NDF content of the TMR) when calculating peNDF intake (Yang and Beauchemin, 2006a). Sorting against longer particles that are high in NDF content, and for the finest particles that are low in NDF would have resulted in lower estimates of dietary peNDF intake based on fractional NDF retention on the particle separator screens.

Interestingly, greater selection against the longest ration particles was associated with greater efficiency of milk production [efficiency ( $\mathrm{kg}$ of milk $/ \mathrm{kg}$ of DMI) $=-0.006 \times$ sorting of long particles $(\%)+2.04 ; P$ $=0.016]$. This is not entirely surprising given that increased consumption of longer ration particles would correspond to an increase in forage intake, which would

Table 4. Production results for primiparous and multiparous cows $\left(\mathrm{L}^{1}\right)$ during 3 different time points during lactation $\left(\mathrm{W}^{2}\right)$

\begin{tabular}{|c|c|c|c|c|c|c|c|c|c|}
\hline Item & \multicolumn{3}{|c|}{ Primiparous } & \multicolumn{3}{|c|}{ Multiparous } & SE & \multicolumn{2}{|c|}{$P$-value } \\
\hline DMI, $\mathrm{kg} / \mathrm{d}$ & 21.0 & 21.9 & 22.7 & 24.2 & 25.9 & 25.5 & 0.72 & $<0.001$ & 0.002 \\
\hline Milk yield, kg/d & 36.0 & 35.0 & 34.1 & 44.3 & 42.3 & 39.9 & 1.51 & $<0.001$ & $<0.001$ \\
\hline $3.5 \%$ FCM yield, $\mathrm{kg} / \mathrm{d}$ & 34.0 & 32.7 & 32.1 & 41.5 & 40.3 & 37.8 & 1.31 & $<0.001$ & $<0.001$ \\
\hline Milk fat, $\%$ & 3.27 & 3.24 & 3.30 & 3.17 & 3.27 & 3.30 & 0.08 & 0.83 & 0.17 \\
\hline Efficiency $^{4}$ & 1.72 & 1.60 & 1.50 & 1.85 & 1.63 & 1.57 & 0.07 & 0.25 & $<0.001$ \\
\hline FCM efficiency $^{5}$ & 1.66 & 1.53 & 1.44 & 1.74 & 1.57 & 1.50 & 0.06 & 0.32 & $<0.001$ \\
\hline BHBA, mg/dL & 14.3 & 14.9 & 15.4 & 14.6 & 14.1 & 15.2 & 0.62 & 0.58 & 0.06 \\
\hline $\mathrm{NEFA}, \mu \mathrm{Eq} / \mathrm{L}$ & 133.7 & 87.2 & 75.1 & 123.5 & 79.3 & 69.4 & 12.0 & 0.34 & $<0.001$ \\
\hline Insulin, IU/mL & 6.2 & 8.6 & 8.8 & 6.7 & 8.1 & 9.8 & 1.20 & 0.75 & $<0.001$ \\
\hline Glucose, $\mathrm{mg} / \mathrm{dL}$ & 57.8 & 60.5 & 58.8 & 57.4 & 56.0 & 57.5 & 1.32 & 0.06 & 0.69 \\
\hline
\end{tabular}

${ }^{1} 30$ primiparous and 30 multiparous cows.

${ }^{2}$ Recording wk 2, 6, and 10 of a 10-wk experimental period. Cows averaged 53, 81, and $109 \pm 10$ DIM at the beginning of each of the 3 recording weeks.

${ }^{3}$ Standard deviation in DMI collected across $7 \mathrm{~d}$ of each recording week.

${ }^{4} \mathrm{~kg}$ of milk/ $\mathrm{kg}$ of DMI.

${ }^{5} \mathrm{~kg}$ of $\mathrm{FCM} / \mathrm{kg}$ of DMI. 
decrease feed conversion efficiency (Yang and Beauchemin, 2006b). Our prediction was that a high degree of sorting against the longer, higher-effective fiber particles and for the shorter, higher-starch particles may increase the risk of SARA in these cows (DeVries et al., 2008) and decrease the efficiency of production (Nocek, 1997). Given the degree of sorting observed in this study (on average $<10 \%$ refusal of long particles), the potential effect on rumen $\mathrm{pH}$ would not have been severe (e.g., decrease in maximum rumen $\mathrm{pH}$ of 0.2 for $10 \%$ difference in sorting behavior; DeVries et al., 2008). In situations where sorting against long particles is more substantial (i.e., 20-30\% refusal of long particles, for example when feeding a lower forage ration with a smaller percentage of long particles; DeVries et al., 2007), a much greater resultant risk of SARA and decrease in efficiency of milk production would occur. It must be noted, however, that, in this study, greater selection against the longest ration particles tended to be associated with lower milk fat percentage [milk fat $\%=0.006 \times$ sorting of long particles $(\%)+2.82 ; P$ $=0.08]$. This suggests that, within the range of sorting against long particles observed (72 to 109\%), some effects on rumen $\mathrm{pH}$ may have occurred, resulting in decreases in milk fat production (Plaizier et al., 2008).

The extent of the observed sorting against the long ration particles and for the fine ration particles was greater for the PP cows across all 3 observation periods (Table 3). Sorting against peNDF and for CP also tended to be greater in the PP cows. The PP cows also sorted for the short ration particles, whereas the MP cows did not. Interestingly, these differences in sorting patterns are similar to those reported by Leonardi et al. (2005), who found that PP cows sorted to a greater extent in favor of short particles, and against the longer particles than did MP cows. To our knowledge, the only other study to report a test of parity on sorting behavior is Leonardi and Armentano (2003); in that study, parity was not significant in their model. Leonardi et al. (2005) hypothesized, without explanation, that the difference in parity results between their study and that of Leonardi and Armentano (2003) was due to the different types of forages used in those studies (i.e., alfalfa hay or alfalfa hay/silage mix vs. corn and oat silage). Unfortunately, the ration used in the present study contained similar forage elements (alfalfa hay, alfalfa silage and barley silage) to those used in both of those previous studies. The rations in all 3 of these studies also varied in forage inclusion level, particle size distribution, and DM percent, which are all factors that affect feed sorting (Leonardi and Armentano, 2003; DeVries et al., 2007; Felton and DeVries, 2010). Therefore, it is difficult to conclude why the results differed based on the rations used. One possible explanation for the difference in sorting behavior is that PP cows may be more adept at sorting due to the physical size of their prehensile parts. Some data suggest that, in ungulate species, the width of the muzzle is related to the degree of selectivity in the diet; specifically, those ungulates that are more selective have narrower muzzles (Janis and Ehrhardt, 1988). Recognizing potential differences among species, it can be hypothesized that within the bovine species, PP cows, which are smaller in size (including their mouth parts) compared with MP cows, may be able to sort their feed more easily than can MP cows. We encourage further research to truly elucidate the reason for this difference in sorting behavior.

Even though other feeding behaviors were not recorded in the present study, we know from previous research that PP cows demonstrate different feeding patterns from those of MP cows. Researchers have consistently demonstrated that PP cows have lower feeding rates and spend more time feeding per day than do MP cows (Beauchemin et al., 2002; Azizi et al., 2009). Greter and DeVries (2011) recently found that greater amounts of sorting against long ration particles was associated with slower eating rates in lactating dairy cows. This suggests that increased sorting of feed results in longer feeding times. Thus, the observed differences in sorting behavior between PP and MP cows in this present study could, in part, explain previously observed differences in feeding behavior patterns between these groups of cows.

It is worthwhile to note that the cows in this study were individually housed and fed in tie-stalls. It could be hypothesized that the sorting behavior of PP cows may be quite different when housed and group-fed with MP cows in a free-stall barn. In a competitive feeding environment, sorting can decrease the nutritive value of the TMR in the feed bunk, particularly in the later hours after feed delivery (DeVries et al., 2005). In such situations, particularly when competition at the feed bunk exists (i.e., due to high stocking density), PP cows may be forced to choose to compete with MP cows to access (and sort) the TMR immediately after feed delivery or access the bunk at a later time after the feed is picked through, and have less opportunity to be as selective in their consumption. Unfortunately, little is known about the sorting behavior of individual cows fed in groups; thus, we encourage further work in this area.

Interestingly, all cows sorted against $\mathrm{ADF}$ at 53D (Table 3). It was also during that time period that all cows were observed to be mobilizing the most body reserves. Given that ADF represents the least digestible fiber components, it is possible that cows were sorting in a manner to avoid these components in an effort to maximize the digestibility of the feed consumed. 
In addition, all cows exhibited greater selection of $\mathrm{CP}$ in their ration at 53D. It has previously been shown that ruminants will, when in states of nutrient deprivation or imbalance, select for feeds to help meet their nutrient requirements (Tolkamp et al., 1998; Villalba and Provenza, 1999). We encourage further work on determining if cows that are mobilizing body reserves specifically sort their rations to meet their nutritional needs, and if so, to what extent.

\section{CONCLUSIONS}

Overall, despite changes in DMI, production, and efficiency, feed sorting remained consistent in all cows from a period of peak lactation to peak DMI. In this study, across all cows and DIM, greater selection against the longest ration particles was associated with greater efficiency of milk production; however, this sorting pattern also tended to be associated with lower milk fat percentage. Further, PP cows engaged in more sorting against the longest, physically effective ration particles and for the finest ration particles than did MP cows during the observed time period of lactation.

\section{ACKNOWLEDGMENTS}

We thank the personnel at the Dairy Research and Technology Centre (DRTC, Edmonton, AB, Canada) for caring for the cows during this project. We also thank the Dairy Farmers of Canada (Ottawa, ON, Canada), the Canadian Dairy Commission (Ottawa, ON, Canada), Agriculture and Agri-Food Canada (Ottawa, ON, Canada), and AB Vista (Marlborough, UK) for their financial support of this study.

\section{REFERENCES}

AOAC. 2002. Official Methods of Analysis. 17th ed. Association of Official Analytical Chemists, Gaithersburg, MD.

Azizi, O., O. Kaufmann, and L. Hasselmann. 2009. Relationship between feeding behaviour and feed intake of dairy cows depending on their parity and milk yield. Livest. Sci. 122:156-161.

Beauchemin, K. A., M. Maekawa, and D. A. Christensen. 2002. Effect of diet and parity on meal patterns of lactating dairy cows. Can. J. Anim. Sci. 82:215-223.

Block, S. S., W. R. Butler, R. A. Ehrhardt, A. W. Bell, M. E. Van Amburgh, and Y. R. Boisclair. 2001. Decreased concentration of plasma leptin in periparturient dairy cows is caused by negative energy balance. J. Endocrinol. 171:339-348.

Canadian Council on Animal Care. 1993. Guide to the Care and Use of Experimental Animals. Vol. 1. E. D. Olfert, B. M. Cross, and A. A. McWilliam, ed. CCAC, Ottawa, ON, Canada.

Dado, R. G., and M. S. Allen. 1994. Variation in and relationships among feeding, chewing, and drinking variables for lactating dairy cows. J. Dairy Sci. 77:132-144.

DeVries, T. J., K. A. Beauchemin, and M. A. G. von Keyserlingk. 2007. Dietary forage concentration affects the feed sorting behavior of lactating dairy cows. J. Dairy Sci. 90:5572-5579.
DeVries, T. J., F. Dohme, and K. A. Beauchemin. 2008. Repeated ruminal acidosis challenges in lactating dairy cows at high and low risk for developing acidosis: Feed sorting. J. Dairy Sci. 91:3958 3967.

DeVries, T. J., M. A. G. von Keyserlingk, and K. A. Beauchemin. 2005. Frequency of feed delivery affects the behavior of lactating dairy cows. J. Dairy Sci. 88:3553-3562.

Felton, C. A., and T. J. DeVries. 2010. Effect of water addition to a total mixed ration on feed temperature, feed intake, sorting behavior, and milk production of dairy cows. J. Dairy Sci. 93:2651-2660.

Greter, A. M., and T. J. DeVries. 2011. Effect of feeding amount on the feeding and sorting behaviour of lactating dairy cattle. Can. J. Anim. Sci. 91:47-54.

Grummer, R. R. 1993. Etiology of lipid-related metabolic disorders in periparturient dairy cows. J. Dairy Sci. 76:3882-3896.

Holtshausen, L., Y.-H. Chung, H. Gerardo-Cuervo, M. Oba, and K. A. Beauchemin. 2011. Improved milk production efficiency in early lactation dairy cattle with dietary addition of a developmental fibrolytic enzyme additive. J. Dairy Sci. 94:899-907.

Janis, C. M., and D. Ehrhardt. 1988. Correlation of relative muzzle width and relative incisor width with dietary preferences in ungulates. Zool. J. Linn. Soc. 92:267-284.

Kertz, A. F., L. F. Reutzel, and G. M. Thomson. 1991. Dry matter intake from parturition to midlactation. J. Dairy Sci. 74:2290-2295.

Kononoff, P. J., A. J. Heinrichs, and D. R. Buckmaster. 2003. Modification of Penn State forage and total mixed ration particle separator and the effects of moisture content on its measurements. J. Dairy Sci. 86:1858-1863.

Krause, K. M., and G. Oetzel. 2006. Understanding and preventing subacute ruminal acidosis in dairy herds: A review. Anim. Feed Sci. Technol. 126:215-236.

Leonardi, C., and L. E. Armentano. 2003. Effect of quantity, quality and length of alfalfa hay on selective consumption by dairy cows. J. Dairy Sci. 86:557-564

Leonardi, C., K. J. Shinners, and L. E. Armentano. 2005. Effects of different dietary geometric mean particle length and particle size distribution of oat silage on feeding behavior and productivity performance of dairy cattle. J. Dairy Sci. 88:698-710.

Nocek, J. E. 1997. Bovine acidosis: Implication on laminitis. J. Dairy Sci. 80:1005-1028.

Penner, G. B., K. A. Beauchemin, and T. Mutsvangwa. 2007. Severity of ruminal acidosis in primiparous Holstein cows during the periparturient period. J. Dairy Sci. 90:365-375.

Plaizier, J. C., D. O. Krause, G. N. Gozho, and B. W. McBride. 2008. Subacute ruminal acidosis in dairy cows: The physiological causes, incidence and consequences. Vet. J. 176:21-31.

Rode, L. M., W. Z. Yang, and K. A. Beauchemin. 1999. Fibrolytic enzyme supplements for dairy cows in early lactation. J. Dairy Sci. $82: 2121-2126$.

SAS Institute. 2003. User's Guide: Statistics. Version 9.1.3 ed. SAS Institute Inc., Cary, NC.

Tolkamp, B. J., R. J. Dewhurst, N. C. Friggens, I. Kyriazakis, R. F. Veerkamp, and J. D. Oldham. 1998. Diet choice by dairy cows. 1. Selection of feed protein content during the first half of lactation. J. Dairy Sci. 81:2657-2669.

Villalba, J. J., and F. D. Provenza. 1999. Effects of food structure and nutritional quality and animal nutritional state on intake behavior and food preferences of sheep. Appl. Anim. Behav. Sci. 63:145-163.

Yang, W. Z., and K. A. Beauchemin. 2006a. Physically effective fiber: Method of determination and effects on chewing, ruminal acidosis, and digestion by dairy cows. J. Dairy Sci. 89:2618-2633.

Yang, W. Z., and K. A. Beauchemin. 2006b. Increasing the physically effective fiber content of dairy cow diets may lower efficiency of feed use. J. Dairy Sci. 89:2694-2704.

Yang, W. Z., and K. A. Beauchemin. 2006c. Effects of physically effective fiber on chewing activity and ruminal $\mathrm{pH}$ of dairy cows fed diets based on barley silage. J. Dairy Sci. 89:217-228. 